\title{
Investigating The Sustainable Development of Tabriz University Based on Green Management Parameters and Preferences of University Managers
}

\author{
Farhad Bolouri*1, Mahdi Zarghami ${ }^{2}$ \\ ${ }^{1}$ M.Sc student, Faculty of Civil Engineering and Institute of Environment, University of Tabriz, Iran \\ ${ }^{2}$ Professor, Faculty of Civil Engineering and Institute of Environment, University of Tabriz, Iran \\ *corresponding author: f_bolouri@yahoo.com
}

\section{Article Info}

Received:

15 March 2021

Accepted:

25 May 2021

Published:

1 June 2021

DOI:

https://doi.org/10.14710/i sp.2021.11749

\begin{abstract}
In recent years, the destruction of the environment on the one hand and the increase in awareness of the consequences of this great danger on the other hand, has led to global actions and consequently, local actions to protect the environment and sustainable development. One of these actions is the sustainable development of universities. The reason for the importance of this case is, firstly, the goal of the universities themselves, which as the center of knowledge and training of the country's elites, is also at the top of environmental affairs, and secondly, as a center with a large number of students and staff which can have a great impact with action for environment. In this research, by using library studies, field observations and interviews, we try to identify sustainability measures of Iranian universities in order to achieve sustainable development and finally present the results of these measures to improve the methods of establishing sustainable development in universities and provide a comprehensive and complete model taking into account all aspects of sustainable development in universities with special emphasis on the campus and its green management. A questionnaire-based on international and domestic standards on the effectiveness of green management parameters in the sustainable development of Tabriz University was prepared and sent to university administrators and faculty members, and then the top ten rankings of this questionnaire were used using interviews with Tabriz university administrators to be determined their preferences in this regard.
\end{abstract}

\section{Keyword:}

Sustainable Development, Green Management, Multi-Criteria Decision Making, Green University, University of Tabriz.

\section{Introduction}

Universities include office and educational buildings, restaurants, retail, sports equipment and leisure facilities, and integrated laboratory and workshop buildings, and as a small town consume, energy and resources. Today, these small towns are under intense pressure from rising energy and operating costs to consider energy improvement measures 
in energy-efficient buildings and equipment. Student admission is constantly increasing, and on the other hand, the per capita consumption of each student is increasing for various reasons, including increasing indoor air quality and high-speed Internet lines, which has led to increased energy consumption. Rising energy costs, environmental constraints and problems, the depletion of fossil resources, the tremendous added value of these resources, and opportunity costs certainly motivate managers to optimize energy and preserve the environment in universities. The high cost of energy and the insistence of governments and environmental laws on rationalizing the energy consumption of universities have led managers to conclude that doing environmental management and improving energy consumption in universities is not only economical but can lead to improve the university atmosphere and the improvement of the environmental situation inside them, and consequently increase the attractiveness of the classrooms for students and increase the educational productivity and pleasantness of the university environment [1].

For the first time in the world, the issue of a green university and sustainable development was raised by an American. He formed a professional association in 2005 called the Association for Sustainable Development and Advancement of Higher Education, which became known worldwide as AASHE; But now AASHE are the universities that have the highest level of success in green design and its development in the surrounding communities. The world's first university is Colorado State University-Fort Collins, the greenest educational institution in the United States. The space of this university is equipped with the first solar greenhouse, through which the air conditioning of the whole complex has a direct connection with the external space of its outer green head [2]. The university is a micro-ecosystem that poses a variety of environmental problems, from greenhouse gas emissions to noise pollution [3]. Sustainable university policies express the ultimate goals that will be addressed by initial environmental studies or initial sustainability conditions.

There are standards for measuring and ranking universities in terms of green management and sustainability, as well as guiding universities towards greenness and sustainability as much as possible, the two international and domestic examples of which are introduced below. The international version is called UI Green Metric, which annually ranks universities around the world in terms of green management and sustainable development with Policy and Infrastructure, Energy and Climate Change, Waste and Waste Management, Transportation, Education and Research measurements. A number of prestigious universities in Iran, including the University of Tehran, Sharif, Amirkabir, Tarbiat Modares, Tabriz, Zanjan, etc which participate in it. The Iranian version of the Green University criteria has been defined as "Green Level" since 2018 and since then, the Ministry of Science, Research and Technology has been in charge of ranking universities based on the Green Level. The evaluation model of the country's educational institutions is with a green management approach. This model has been formed with the aim of reducing the destructive effects on the environment and improving the level of performance of universities in expanding the community's view of various aspects of green management. This model includes several sections of areas, indicators, tools and implementation strategies. The main areas of the green balance model are discussed in three sections: green environmental management, green science management and green socio-cultural management. In the tools section, we encounter relationships and arrangements for measuring and evaluating each indicator that relationships deal with a criterion in a quantitative way and require numerical data. Preparations are also foreseen in the form of codified plans and executive measures in various fields to measure some indicators. 
Regarding the description of the Green Level model, a fixed classification has been considered in order to simplify its use for the integration of the manual. Green Level model according to three main aspects of the sustainable development perspective; The economic, environmental and social fields on the one hand and the educational and research mission of universities on the other hand have been inspired by the existing models of evaluation and ranking of green universities.

In this research, first, the criteria of sustainable university development collected from international and domestic standards are introduced in an edited and categorized based on the categories of sustainable development. Then, the results of the questionnaire, which consists of the introduced components and was sent to the university administrators and interviewed, are analyzed and the preferences of Tabriz university administrators are discussed as a case study. A questionnaire-based on international and domestic standards on the effectiveness of green management parameters in the sustainable development of Tabriz University was prepared and sent to university administrators and faculty members, and then the top ten rankings of this questionnaire were used using interviews with Tabriz university administrators to be determined their preferences in this regard.

\section{Literature review}

Many studies have been done in the field of green management of universities, some of which are mentioned below.

Faghihimani (2012) in her research has analyzed the concepts of sustainability and sustainable development from a systemic perspective. In addition, she has used cybernetic theory and the living system model for sustainability in higher education institutions to show how environmental sustainability can be implemented in higher education institutions in a systematic and live way. Finally, based on the developed model, he analyzed the environmental sustainability performance of the University of Oslo in detail and represented the process of implementing the sustainability and progress of the university in this field. In this study, he showed that the University of Oslo has made progress in the field of environmental sustainability indicators. The results of this study show that the performance of the University of Oslo in terms of governance and management has improved by supporting environmental sustainability policies. And their policy in this regard has been based on the Copernican Charter [4].

Malekinia et al. (2014) in examining the components of a sustainable university showed that the components of sustainable management, sustainable education system, sustainable research system, environmental management system, sustainable financing system and providing specialized services, respectively, are the most important in Have had a university sustainability [5].

Wiganingrum (2018) in his research to develop the Deepongoro University Campus Sustainability Assessment Framework (UNDIP) stated that; The sustainability of the campus has been considered by global programs as a result of the impact of university activities on the environment. The use of university sustainability in Indonesia, particularly UNDIP, has not yet been widely used. There are several phenomena in UNDIP regarding the sustainability of the university. This study evaluates the university sustainability assessment at UNDIP. The framework used is the framework developed by Alghamdi in 2017. The AHP method will be used to determine the priorities of the main criteria, sub-criteria and indicators of the framework. Priority output will be used to calculate the stability score in 
UNDIP by multiplying the weight and scale of each index. This research has shown that there are 5 main criteria, 14 sub-criteria and 35 indicators [6].

Omidifar et al. (2018) in their research stated that the study of educational inequality and its elimination or reduction is an issue that researchers and governments pay attention to; Therefore, in the present study, inequality and ranking of universities in Tehran were studied to achieve sustainable development. In this study, universities were evaluated in two categories: documentary and non-documentary indicators, and a combination of indicators. The statistical population included students of Tehran University. For sampling, the stratified method with an appropriate assignment was used. Also, 383 people were selected for the sample and a questionnaire was distributed among them. The type of research was descriptive-analytical and the information was collected in the field and library. The purpose of the research was also applied. A questionnaire was used to assess the components and the validity of the indicators was validated with the opinion of relevant professors and experts. The TOPSIS model was used to rank universities in terms of research indicators. According to the findings, the University of Tehran ranks first in most indicators. Tehran universities are different in terms of having different indicators. Comprehensive universities, the University of Tehran, Tarbiat Modares and Shahid Beheshti are in the first to third places, respectively. Sharif, Amir Kabir, Elm-o-Sanat and Khajeh Nasir al-Din Tusi universities of engineering and technology have the first to fourth ranks, respectively [7].

As can be seen, research has been conducted on the green management of universities, but the views of university administrators across the country as well as the preferences of university administrators have not been studied in detail. This research, deals with this important issue and examines the views of university administrators throughout Iran and then the preferences of University of Tabriz administrators as a case study.

\section{Methods and Materials}

\section{a. University of Tabriz as a Case study}

The University of Tabriz started its work in 1326 with two faculties of literature and medicine and now with more than 21 faculties, 10 research institutes and research groups, 5 scientific poles, more than 800 faculty members, 24,000 students and 1,000 Administrative staff is engaged in training skilled and specialized human resources. University of Tabriz camps with an area of 600 hectares, very pleasant green space and more than 50,000 trees in a quiet environment with facilities such as student market, bakery, laundry, post office, photographer, mosque, cultural and artistic centers, cinema, Permanent exhibitions and etc.

\section{b. Components of university sustainable development categorized}

Based on several international and domestic standards, as well as the study of dissertations and articles on university sustainable development, the components of university sustainable development were categorized according to the Global Sustainable Development category. The components and their classifications are shown in Table 1.

Table1. Components of university sustainable development

\begin{tabular}{|c|c|c|}
\hline classification & Row & Component \\
\hline \multirow{2}{*}{ 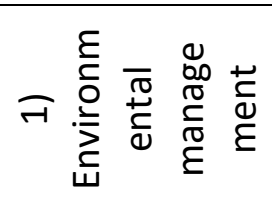 } & 1 & $\begin{array}{l}\text { Paying attention to environmental issues in building maintenance } \\
\text { and also paying attention to environmental issues in new university } \\
\text { constructions (sustainable architecture) }\end{array}$ \\
\hline & 2 & Reduce energy consumption and use clean energy \\
\hline
\end{tabular}




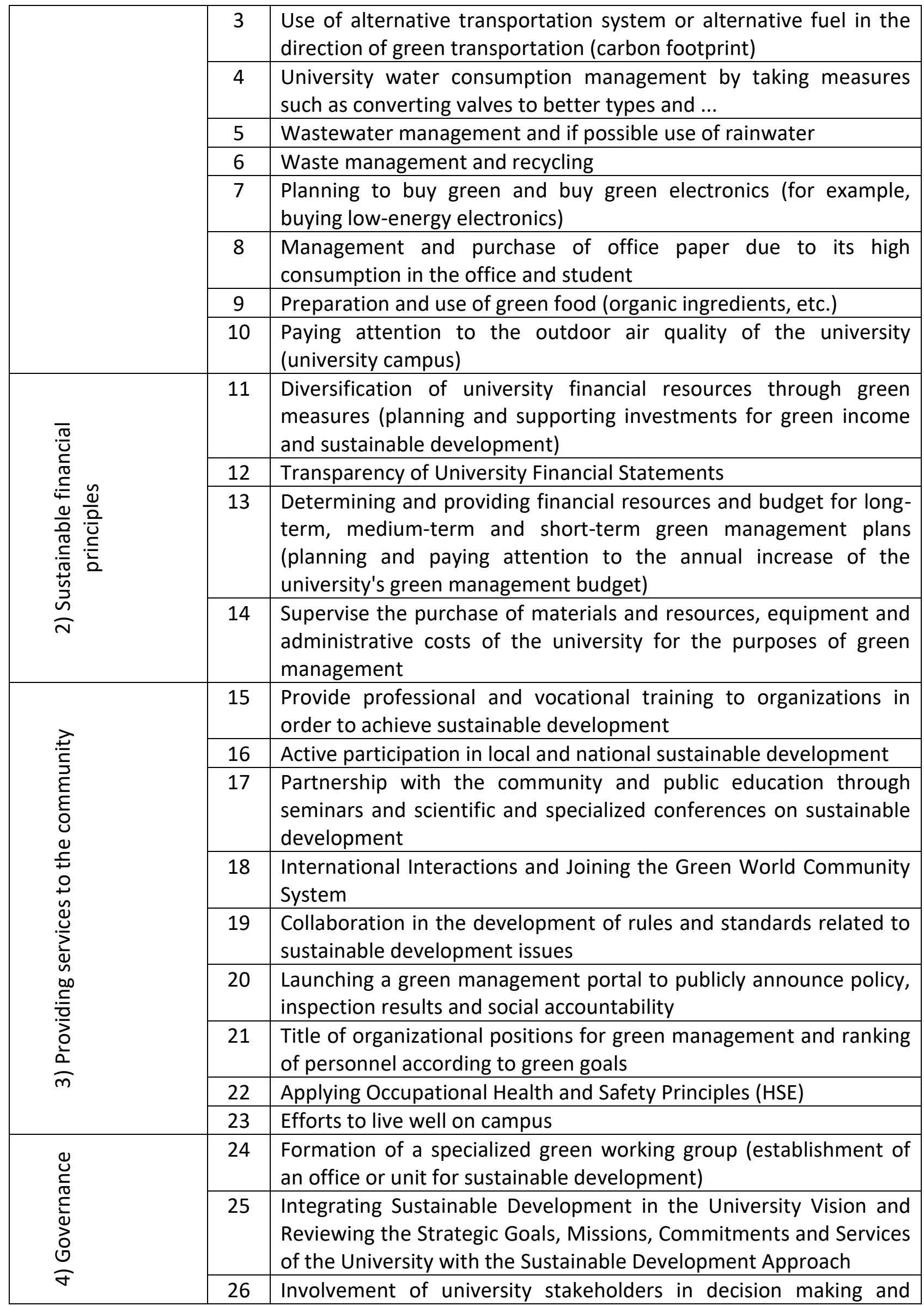




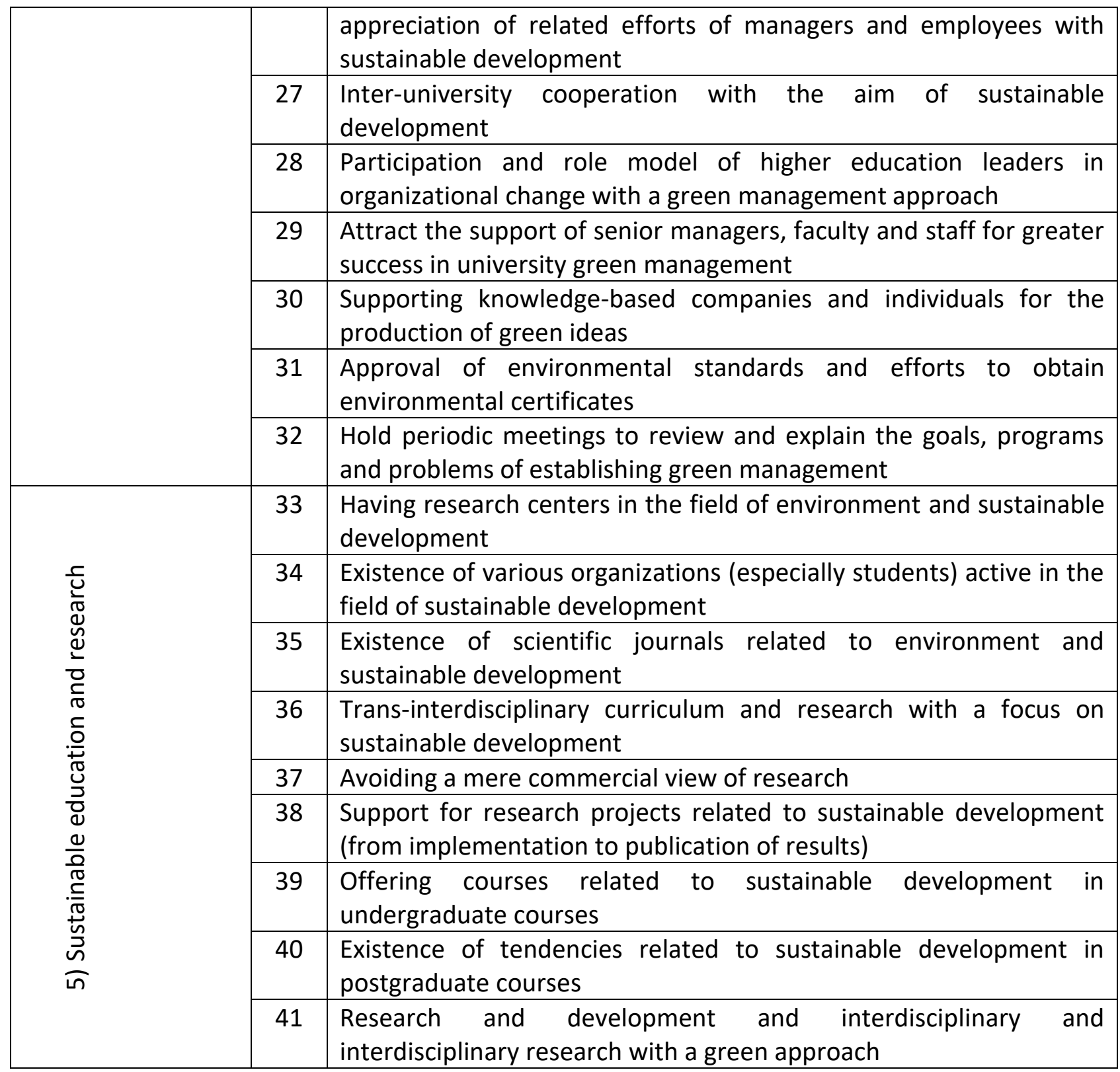

A questionnaire containing the components of Table 1 was sent to professors and university administrators across Iran. Then, the top 10 reasons were selected and during interviews with Tabriz university administrators, these top ten reasons were examined to determine their preferences. The results will be reviewed below.

\section{Results and discussion}

In this research, a questionnaire was prepared based on the components introduced in the previous section, as well as several other questions, which were first reviewed by university professors and questionnaire experts and then online in the "porsline.ir" environment Written and delivered via email and cyberspace to university sustainable development professionals, including professors of environment, economics, social sciences and urban planning, as well as staff and decision-makers in the university's green management department; it placed. Out of more than 200 emails sent, 34 were answered 
reliably, and the following results are obtained from the analysis of these responses. The respondents are as follows.

The ranking section of the research questionnaire is based on "Likert 5 options" including "Very strong impact on sustainable university development", "Strong impact on sustainable university development", "Medium impact on sustainable university development", "Impact "Weak on the sustainable development of the university" and "Very weak impact on the sustainable development of the university."

According to the respondents' ranking, the component of "reducing energy consumption and the use of clean energy" is in the first place, which shows the importance of reducing energy consumption in universities as a fully consuming unit for the country and Also, the move towards the use of clean energy is due to the use of new technologies in the university. The component of "active participation in local and national sustainable development" was identified as the second rank, which can be attributed to the main task of the university, which is to provide services to the community. "Attracting the support of senior managers, faculty and staff for greater success in university green management" ranked third as an important component in sustainable university development; Because encouraging towards the goals of sustainable development and public cooperation in achieving these goals is one of the basic pillars of sustainable development and the seventeenth goal of the seventeen goals of sustainable development, which is also considered in the sustainable development of academia. has taken. Top ten items interviewed are ranked in Table 2.

Table2. Ranking of components of sustainable university development

\begin{tabular}{|c|c|c|c|c|c|c|c|}
\hline Rank & Component & 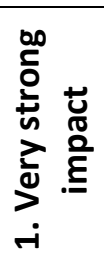 & 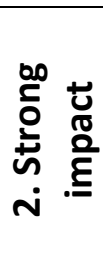 & 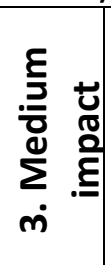 & 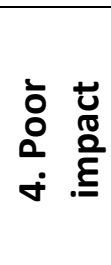 & 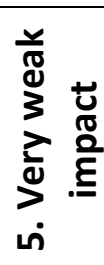 & Average \\
\hline 1 & $\begin{array}{l}\text { Reduce energy consumption and use } \\
\text { clean energy }\end{array}$ & 21 & 12 & 0 & 1 & 0 & 4.56 \\
\hline 2 & $\begin{array}{l}\text { Active participation in local and national } \\
\text { sustainable development }\end{array}$ & 19 & 11 & 3 & 1 & 0 & 4.41 \\
\hline 3 & $\begin{array}{l}\text { Attract the support of senior managers, } \\
\text { faculty and staff for greater success in } \\
\text { university green management }\end{array}$ & 17 & 13 & 14 & 0 & 0 & 4.38 \\
\hline 4 & $\begin{array}{l}\text { Management and purchase of office } \\
\text { paper due to its high consumption in the } \\
\text { office and student }\end{array}$ & 16 & 14 & 4 & 0 & 0 & 4.35 \\
\hline 5 & $\begin{array}{l}\text { Diversification of university financial } \\
\text { resources through green measures }\end{array}$ & 15 & 15 & 4 & 0 & 0 & 4.32 \\
\hline 6 & $\begin{array}{l}\text { Supporting knowledge-based companies } \\
\text { and individuals for the production of } \\
\text { green ideas }\end{array}$ & 16 & 14 & 3 & 1 & 0 & 4.32 \\
\hline 7 & Waste management and recycling & 16 & 12 & 6 & 0 & 0 & 4.29 \\
\hline 8 & $\begin{array}{l}\text { Providing professional and job training } \\
\text { to organizations in order to achieve } \\
\text { sustainable development }\end{array}$ & 18 & 10 & 5 & 0 & 1 & 4.29 \\
\hline
\end{tabular}




\begin{tabular}{|c|l|c|c|c|c|c|c|}
\hline 9 & $\begin{array}{l}\text { Research and development and } \\
\text { interdisciplinary and interdisciplinary } \\
\text { research with a green approach }\end{array}$ & 18 & 9 & 6 & 1 & 0 & 4.29 \\
\hline 10 & $\begin{array}{l}\text { Integrating Sustainable Development in } \\
\text { the University Vision and Reviewing the } \\
\text { University's Strategic Goals, Missions, } \\
\text { Commitments and Services with the } \\
\text { Sustainable Development Approach }\end{array}$ & 11 & 21 & 2 & 0 & 0 & 4.26 \\
\hline
\end{tabular}

From the senior managers of Tabriz University; Factors: "Reducing energy consumption and use of clean energy", "Diversification of university financial resources through green measures (planning and supporting investments for green income and sustainable development)" and "Active participation in local sustainable development" And "national" preferred. Also from the senior managers of Tabriz University campus, the factors of "waste management and recycling", "attracting the support of senior managers, faculty and staff for more success in green management of the university" and "providing professional and job training to organizations in order to achieve They preferred "sustainable development".

Experts on budget, organization, administrative transformation and productivity stressed that legally the university should provide two types of services: 1) education services and 2) research services. Of course, type 3 is also offered now, and that is student services (welfare and culture).

In general, it can be stated that items such as "reducing energy consumption and use of clean energy", "attracting the support of managers for green management" and "active participation in sustainable local development" are among the top-ranked items in the questionnaire. They have also been in the preferences of Tabriz university administrators.

\section{Conclusion}

In this study, an online questionnaire was prepared and the components of sustainable university development were sent to experts (related professors and staff working in the field of university green management) of top universities in Iran for scoring. The components of "reduction of energy consumption and use of clean energy" with a score of 4.56, "active participation in sustainable local and national development" with a score of 4.41 and "attracting the support of senior managers, faculty and staff" For more success in the green management of the university "with a score of 4.38 out of 5 , they were ranked first to third, respectively. It was observed that all the specialized groups agreed on the top component and their average ranking was almost the same and close to each other. It was also clearly seen that the direction of work expertise was observed in the opinion of individuals; For example, university governance has placed more emphasis on the thirdranked component of "attracting the support of senior executives, faculty, and staff to be more successful in green university management" than other groups because of its familiarity and Most of his expertise has been in the subject of "university staff". But the same group has been more cautious about the other components, and their scores have always been lower than the overall average. 


\section{References}

1. SeyedAlavi, M. 2017. Providing a model for applying green management in public universities in Tehran. PhD thesis. Urmia University. Faculty of Literature and Humanities. Department of Educational Sciences. (In Persian). http://www.aashe.org

2. United Nations Environment Programme (UNEP). 2013. Greening universities toolkit transforming universities into green and sustainable campuses: a toolkit for implementers.

3. Faghihimani, M. 2012. A systemic approach for measuring environmental sustainability at higher education institutions. A case study of the University of Oslo [dissertation]. [Oslo] Institute for Educational Research, Faculty of Education, University of Oslo.

4. Malekinia, E., Bazargan, A., Vaezi, M. and Ahmadian, M. 2014. "Identifying and prioritizing the components of a sustainable university", Research and Planning in Higher Education, 20th year, No. Volume 26, pp 3-1.

5. Wiganingrum, R., Handayani, N. U., \& Suliantoro, H. 2018. Framework Development of Campus Sustainability Assessment. Case Study: Diponegoro University. In E3S Web of Conferences, Vol. 73, p. 02004 EDP Sciences.

6. Omidifar, Reza., Qalaei, Alireza., Hassani, Mohammad. And Mousavi, Mir Najaf. 2018. Explaining inequality and ranking of Tehran universities in order to achieve sustainable development. Human Geography Research Volume 50. Number 3,consecutive 105, pp 5139. 